\title{
IMPLANT STABILITY IN ADULTS AND CHILDREN IMPLANTED WITH NON-PIN OR PIN COCHLEAR IMPLANT VARIANTS: SUCCESS WITH DIFFERENT SURGICAL TECHNIQUES
}

\author{
Robert Mlynski ${ }^{1}$, Astrid Magele ${ }^{2}$, Wolf-Dieter Baumgartner ${ }^{3}$, \\ Benoit Godey ${ }^{4}$, Thomas Stark ${ }^{5}$, Andreas Radeloff 6 , Rudolf Hagen?, \\ Markus Brandstetter ${ }^{8}$, Alexandra Jappel ${ }^{9}$, Georg Sprinzl ${ }^{2}$
}
${ }^{1}$ Department of Otorhinolaryngology, Head and Neck Surgery, Otto Koerner Rostock University Medical Center, Rostock, Germany
${ }^{2}$ St Poelten University Hospital, ENT Department, St Poelten, Austria
${ }^{3}$ Vienna General Hospital - Medical University Campus, University Hospital of Ear, Nose \& Throat Diseases, Vienna, Austria
${ }^{4} \mathrm{CHU}$ de Rennes, Hôpital Pontchaillou, Service ORL, Rennes, France
${ }^{5}$ Helios Klinikum Muenchen West, ENT Department, Munich, Germany
${ }^{6}$ Oldenburg University Hospital, ENT Department, Oldenburg, Germany
${ }^{7}$ Wuerzburg University Hospital, Hospital of Ear, Nose \& Throat Diseases of Wuerzburg University, Wuerzburg, Germany
${ }^{8}$ ENT Polyclinic, Klinikum rechts der Isar, Munich Technical University, Munich, Germany ${ }^{9}$ Heidelberg University Hospital, ENT Department, Heidelberg, Germany

Corresponding author: Univ-Prof Dr med Robert Mlynski, Department of Otorhinolaryngology, Head and Neck Surgery, Otto Koerner Rostock University Medical Center, Doberaner Str 137-139, D-18057 Rostock, Germany; tel: +49 381 4948301; e-mail: robert.mlynski@med.uni-rostock.de

\begin{abstract}
Background: The primary aim of this study was to collect information on the surgical procedures used to implant two cochlear implant variants (non-pin and pin: Concerto and Concerto Pin from Med-El) in adults and children and to assess their medium-term stability. A secondary aim was to assess the safety of these variants, both of which permit a minimally invasive surgical protocol to be used. The pin variant has greater flexibility in positioning and fixing of the implant, with the pins ensuring implant stability; also it requires less or no drilling and no tie-down sutures.

Materials and Methods: Non-pin and pin cochlear implant variants (Concerto and Concerto Pin from Med-El) were implanted in adults and children $(n=116)$ in 5 clinics. The different surgical techniques and methods of implant fixation were documented intraoperatively. Implant stability was subjectively assessed at first fitting and again approximately 3 and 6 months later. Safety was assessed based on the number and severity of adverse events.
\end{abstract}

Results: With all non-pin variants suture fixation was always performed, but with the pin variant this was done for just $43 \%$ of adults and $49 \%$ of children (in the remainder, no additional fixation was performed). The study demonstrated the stability of both cochlear implant variants in children and adults, with no shifting or rocking observed. There were 33 adverse events reported during the study, 10 of which (9\%) were classified as related to the device or procedure.

Conclusions: Implant stability and safety can be achieved through various surgical techniques and fixation methods when implanting either the Concerto or Concerto Pin.

Key words: fixation • immobilization • minimally invasive surgery

DIFERENTES TÉCNICAS QUIRÚRGICAS PARA GARANTIZAR LA ESTABILIDAD DEL IMPLANTE EN ADULTOS Y NIÑOS CON IMPLANTES COCLEARES DE TIPO NON-PIN Y PIN

\section{Resumen}

Introducción: El objetivo principal de este estudio fue recopilar opiniones sobre los procedimientos quirúrgicos utilizados para implantar dos tipos de implantes cocleares (non-pin y pin) en adultos y niños y evaluar la estabilidad a medio plazo de estos dos tipos de implantes. El segundo objetivo fue evaluar la seguridad de estos dos tipos de implantes. Ambos tipos de implantes permiten el uso de un protocolo 
quirúrgico mínimamente invasivo. El tipo pin proporciona una mayor flexibilidad para posicionar y fijar el implante. Los pasadores (pins) aseguran la estabilidad del implante. En tales procedimientos quirúrgicos hay una tasa menor o nula de perforación y no hay suturas de sujeción.

Materiales y métodos: Se utilizaron los tipos de implantes cocleares de tipo pin y non-pin en adultos y niños ( $\mathrm{n}=116$ ) en 5 clínicas. Se han documentado diversas técnicas quirúrgicas y métodos de fijación de implantes intraoperatoriamente. La estabilidad del implante se evaluó subjetivamente en el primer ajuste y aproximadamente a los 3 y 6 meses después del primer ajuste. La seguridad se evaluó en función del número y la gravedad de las complicaciones.

Resultados: Se utilizaron suturas fijas para todos los implantes non-pin, y en el $43 \%$ de adultos y $49 \%$ de niños con el implante tipo pin implantado. En el resto de adultos y niños con un implante tipo pin implantado, no se realizado fijaciones adicionales. El estudio mostró la estabilidad de ambos tipos de implante coclear en niños y adultos; no se han observado desplazamientos ni balanceos. Se informaron 33 eventos adversos durante el estudio, de los cuales 10 (9\%) se clasificaron como relacionados con el dispositivo o procedimiento.

Conclusiones: La estabilidad y la seguridad del implante se puede lograr mediante varias técnicas quirúrgicas y métodos de fijación.

Palabras clave: fijación • inmovilización • cirugía mínimamente invasiva

\title{
РАЗЛИЧНЫЕ ХИРУРГИЧЕСКИЕ ТЕХНИКИ, ОБЕСПЕЧИВАЮЩИЕ СТАБИЛЬНОСТЬ ИМПЛАНТА У ВЗРОСЛЫХ И ДЕТЕЙ С КОХЛЕАРНЫМИ ИМПЛАНТАМИ ТИПА NON-PIN И РIN
}

\begin{abstract}
Аннотация
Введение: Основной целью данного исследования является сбор информации о хирургических процедурах, используемых при двух типах кохлеарной имплантации: non-pin и pin (без фиксирующих титановых штырьков и с фиксирующими титановыми штырьками) у взрослых и детей, и оценка среднесрочной стабильности этих двух типов импланта. Следующая цель заключалась в оценке безопасности данных видов имплантов. Оба типа импланта позволяют использовать минимально инвазивный хирургический протокол. Тип фиксации обеспечивает большую гибкость в размещении и фиксации импланта. Штырьки обеспечивают стабильность импланта. При таких хирургических процедурах сверления достаточно мало или оно совсем отсутствует, а шовной фиксации нет.

Материалы и методы: Типы кохлеарных имплантов pin и поn-pin были использованы у взрослых и детей $(\mathrm{n}=116)$ в 5 клиниках. Во время операции были зафиксированы различные хирургические техники и методы крепления имплантов. Стабильность импланта оценивалась субъективно при первой настройке и примерно через 3 и 6 месяцев после первой настройки. Безопасность оценивалась на основании количества и тяжести побочных эффектов.

Результаты: Шовная фиксация была использована в случае всех имплантов поn-pin, а также у 42,86\% взрослых и 48,78\% детей с имплантом pin. У оставшегося числа взрослых и детей с имплантом ріп не было использовано никаких дополнительных креплений. Исследование показало стабильность обоих типов кохлеарного импланта у детей и взрослых; смещения не наблюдалось. В ходе исследования было зарегистрировано 33 побочных эффекта, из которых 10 (8,7\%) были классифицированы как относящиеся к устройству или процедуре.
\end{abstract}

Выводы: Стабильность и безопасность импланта могут быть достигнуты с помощью различных хирургических техник и методов крепления.

Ключевые слова: крепление • иммобилизация • малоинвазивная хирургия

\section{RÓŻNE TECHNIKI CHIRURGICZNE ZAPEWNIAJĄCE STABILNOŚĆ IMPLANTU U DOROSŁYCH I DZIECI Z WSZCZEPIONYM IMPLANTEM ŚLIMAKOWYM TYPU NON-PIN I PIN}

\section{Streszczenie}

Wstep: Głównym celem tego badania było zebranie opinii na temat procedur chirurgicznych stosowanych do implantacji dwóch typów implantu ślimakowego (non-pin i pin) u dorosłych i dzieci oraz ocena średnioterminowej stabilności tych dwóch typów implantu. Drugim celem była ocena bezpieczeństwa tych dwóch typów implantu. Oba typy implantu pozwalają na zastosowanie minimalnie inwazyjnego protokołu chirurgicznego. Typ pin zapewnia większą elastyczność w pozycjonowaniu i mocowaniu implantu. Szpilki (pins) zapewniają stabilność implantu. W takich procedurach chirurgicznych jest mniej lub w ogóle brak wiercenia oraz brak szwów mocujących.

Materiały i metody: Typy implantów ślimakowych pin i non-pin zostały zastosowane u dorosłych i dzieci $(n=116)$ w 5 klinikach. Różne techniki chirurgiczne i metody mocowania implantu zostały udokumentowane śródoperacyjnie. Stabilność implantu oceniano subiektywnie przy pierwszym dopasowaniu i około 3 i 6 miesięcy po pierwszym dopasowaniu. Bezpieczeństwo oceniono na podstawie liczby i stopnia uciążliwości zdarzeń niepożądanych.

Wyniki: Szwy mocujące zostały zastosowane dla wszystkich implantów typu non-pin oraz u 43\% dorosłych i $49 \%$ dzieci z wszczepionym implantem pin. U pozostałych dorosłych i dzieci z wszczepionym implantem pin nie robiono żadnych dodatkowych mocowań. Badanie wykazało stabilność obu typów implantu ślimakowego u dzieci i dorosłych; nie zaobserwowano przesunięcia ani kołysania. Podczas badania zgłoszono 33 zdarzenia niepożądane, z czego 10 (9\%) sklasyfikowano jako związane z urządzeniem lub procedurą.

Wnioski: Stabilność i bezpieczeństwo implantu można osiągnąć za pomocą różnych technik chirurgicznych i metod mocowania.

Słowa kluczowe: mocowanie $\bullet$ unieruchomienie $\bullet$ chirurgia małoinwazyjna 


\section{Background}

The surgical technique most commonly recommended for cochlear implantation by cochlear implant (CI) manufacturers is to drill a bony well to accommodate the receiver-stimulator and to fix the device with non-absorbable (permanent) sutures [1,2]. However, in recent years minimally invasive surgery, involving only a small incision and the flattening of the skull for the receiver-stimulator, has established itself as a widely used surgical technique for cochlear implantation $[3,4]$. Such an approach is particularly beneficial for subjects with thinner bones and thinner soft tissue, such as children and the elderly $[5,6]$. Minimally invasive surgery often goes along with alternative fixation techniques, such as the use of titanium plates, absorbable plates, different types of mesh, Gore-Tex sheets, or titanium screws combined with non-absorbable or absorbable sutures [1,7-9]. Sutureless fixation using a periosteal pocket or a temporalis muscle pocket with no drilling of a bony well have also been reported to be safe surgical techniques [10-12]. Minimally invasive surgery is less time-consuming and thus allows shorter total surgery time $[9,13,14]$. In turn, reduced surgery duration minimizes the impact of anesthesia on the subject, which is important when the elderly or very young children undergo surgery [15].

The primary aim of this study was to collect information on the surgical procedures used to implant two cochlear implant variants, non-pin and pin, in adults and children (Concerto and Concerto Pin from Med-El, Innsbruck, Austria) and to subjectively assess the medium-term stability of these two variants. A secondary aim was to assess their safety based on the number and severity of adverse events. The implant variants investigated in this study allow the use of a minimally invasive surgical protocol. The pin variant, in particular, specifically aims for greater flexibility in positioning and fixing the implant on the skull, with the pins ensuring stability. Additionally, less (or no) drilling and no tie-down sutures are required [14].

\section{Material and Methods}

\section{Subjects}

Subjects were eligible for the study if they were CI candidates to be implanted either with the non-pin or pin variant. Subjects had to meet the CI candidate selection criteria of the respective implant centers. Those excluded from participation were reimplantation candidates, subjects with autoimmune disease, meningitis, ossification of the cochlea, or any disorder causing an increased risk of skin flap problems. The study comprised 4 different groups: Group 1: adults implanted with the non-pin variant; Group 2: children implanted with the non-pin variant; Group 3: adults implanted with the pin variant; Group 4: children implanted with the pin variant.

There were 117 eligible subjects in 5 study sites located in Austria, France, and Germany (Innsbruck, Vienna, Rennes, Munich, and Wuerzburg) who met the inclusion criteria and were recruited for the study. The subjects were divided into 4 groups as set out above. The total number of recruited adults (> 18 years) was 49 . Of these, 21 were implanted with the non-pin variant (Group 1) and 28 with the pin variant (Group 3). The total number of recruited children ( $<18$ years) was 68 . Of these, 26 were implanted with the non-pin variant (Group 2) and 41 with the pin variant (Group 4). One child was not implanted because no auditory nerve could be detected during a preoperative MRI. This subject was withdrawn before surgery. Therefore, data analysis was performed on the 116 remaining subjects.

\section{Devices}

The present study investigated 2 cochlear implant variants. The Concerto and Concerto Pin implant variants were developed based on the Sonata TI100 from Med-El [16]. The major difference to the Sonata TI100 is that the thickness of the titanium housing is reduced to $4.5 \mathrm{~mm}$ (including overmold), which also leads to reduced mass and volume ( $7.6 \mathrm{~g}$ and $3.7 \mathrm{~cm}^{3}$ respectively). In contrast to the usual flat bottom of the implant housing of the non-pin variant (Concerto, Figure 1), the pin variant (Concerto Pin, Figure 2) features two $1.4 \mathrm{~mm}$ long titanium pins protruding from the flat bottom to facilitate fixation of the implant to the skull [17].

\section{Study design and procedure}

This was an observational, prospective, longitudinal multi-center study conducted between 2011 and 2014 using a single-subject, repeated-measures design. Surgical procedures were documented intraoperatively; implant stability

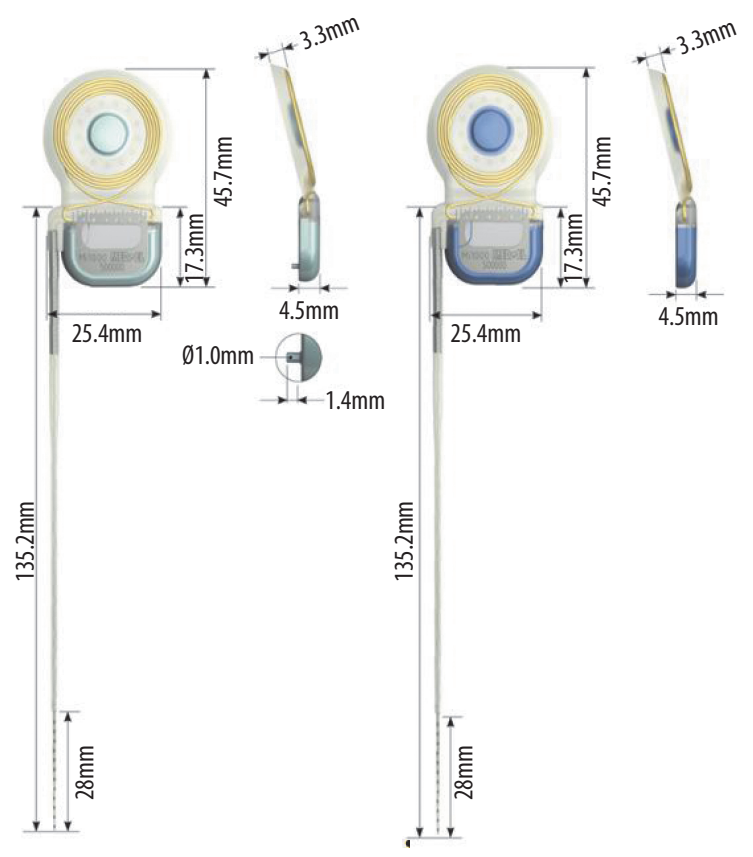

Figure 1. The non-pin variant of the MedEl Concerto cochlear implant. Dimensions are in millimeters. (Figure courtesy of Med-El)
Figure 2. The pin Pin). Dimensions in millimeters. (Figure courtesy of Med-El) variant (Concerto 
was subjectively assessed at first fitting, and again about 3 and 6 months later. Safety was assessed based on the number and severity of adverse events. For this assessment, subjects were followed for a period of between 1.1 and 15.3 months (mean 7.2 months) after surgery.

All surgeons involved in this study were free to follow their preferred routine surgical steps, in particular with regard to skin incision, preparation of the implant bed, implant fixation, and placement of the electrode. Different forms of suture fixation techniques were used by each surgical team (see Tables 1 and 2). The suture fixation techniques can be classified into two main categories: single-stitch suture and web-stitch suture.

During surgery, the surgical procedures were documented, including implant type, incision details, skin flap measurement, preparation of the implant bed, fixation of the implant, electrode insertion, and complications during surgery.

Immediately after the activation of the audio processor (approximately 1 month after implantation), the first fitting assessment was performed. Some 3 months and 6 months later, post-fitting assessments were performed. At each postoperative assessment, it was documented if the receiver-stimulator implanted under the scalp was stable (no shifting or rocking) by gently feeling the receiverstimulator. Any adverse events were also documented at each assessment.
Stability and safety of the implants were assessed individually for each of the four groups. To statistically test the difference between adults and children and between the non-pin and pin variants in terms of variables such as length of skin incision, depth of the implant bed at the anterior edge, or distance from the anterior edge of the implant bed to the edge of the mastoidectomy, a MannWhitney U-test was applied.

\section{Ethics}

All subjects gave written consent. All clinics submitted the investigational plan to local ethics committees and approval was granted for each.

\section{Results}

\section{Group 1: Adults implanted with the non-pin variant}

There were 21 adults who were implanted with the nonpin variant, 17 female and 4 male. Average age at implantation was 60.1 years (range 33.4-82.4; median 61.3 years). There were 10 subjects implanted on the right and 11 on the left. The etiology of hearing loss for the implanted ear was unknown for 15 , congenital/hereditary for 4 , ototoxicity for 1 , and trauma for 1 subject. The average duration of hearing impairment for the implanted ear was 25.7 years (range 10-50; median 21 years) and unknown

Table 1. Surgical details of Groups 1 and 2 (adults and children implanted with the non-pin variant)

\begin{tabular}{|c|c|c|}
\hline Surgical information & Group $1(n=21)$ & Group $2(n=26)$ \\
\hline Mean length of skin incision & $5.9 \mathrm{~cm}$ (range $4.0-8.5 \mathrm{~cm}$; median $5.0 \mathrm{~cm}$ ) & $5.8 \mathrm{~cm}$ (range $3.5-8.0 \mathrm{~cm}$; median $5.3 \mathrm{~cm}$ ) \\
\hline $\begin{array}{l}\text { Type of skin flap } \\
\text {-Single } \\
\text {-Double }\end{array}$ & $\begin{array}{c}16 \\
5\end{array}$ & $\begin{array}{l}11 \\
15\end{array}$ \\
\hline $\begin{array}{l}\text { Mean depth of the implant bed at the } \\
\text { anterior edge }\end{array}$ & $\begin{array}{l}2.8 \mathrm{~mm} \text { (range } 1.5-5.0 \mathrm{~mm} \text {; } \\
\text { median } 2.8 \mathrm{~mm} \text { ) }\end{array}$ & $\begin{array}{l}1.8 \mathrm{~mm}(\text { range } 1.0-4.0 \mathrm{~mm} ; \\
\text { median } 1.75 \mathrm{~mm})\end{array}$ \\
\hline $\begin{array}{l}\text { Mean distance from the anterior } \\
\text { edge of the implant bed to the edge } \\
\text { of the mastoidectomy }\end{array}$ & $\begin{array}{c}10.0 \mathrm{~mm} \text { (range } 4.0-30.00 \mathrm{~mm} \text {; } \\
\text { median } 25.0 \mathrm{~mm} \text { ) }\end{array}$ & $\begin{array}{l}11.2 \mathrm{~mm} \text { (range } 1.0-30.0 \mathrm{~mm} \\
\text { median } 10.5 \mathrm{~mm})\end{array}$ \\
\hline $\begin{array}{l}\text { Fixation technique used for the } \\
\text { implant bed: }\end{array}$ & $\begin{array}{c}\text { Sutures + bone pâté (1) } \\
\text { Sutures + bone pâté } \\
+ \text { periosteal pocket }(19) \\
\text { Sutures + fibrin glue + periosteal pocket (1) }\end{array}$ & $\begin{array}{c}\text { Sutures + bone pâté }(1) \\
\text { Sutures + bone pâté } \\
+ \text { periosteal pocket }(8) \\
\text { Sutures + fibrin glue + periosteal pocket (17) }\end{array}$ \\
\hline $\begin{array}{l}\text { Suture fixation technique used: } \\
\text { Single stitch } \\
\text { Web stitch }\end{array}$ & $\begin{array}{c}13 \\
8\end{array}$ & $\begin{array}{l}10 \\
16\end{array}$ \\
\hline $\begin{array}{l}\text { Type of suture: } \\
\text { Dissolvable sutures } \\
\text { Permanent sutures }\end{array}$ & $\begin{array}{c}20 \\
1\end{array}$ & $\begin{array}{c}19 \\
6\end{array}$ \\
\hline $\begin{array}{l}\text { Electrode recessed in a ramp-like } \\
\text { channel: } \\
\text {-Completely recessed } \\
\text {-Partially recessed } \\
\text { - Not recessed }\end{array}$ & $\begin{array}{l}19 \\
2 \\
0\end{array}$ & $\begin{array}{l}20 \\
5 \\
1\end{array}$ \\
\hline $\begin{array}{l}\text { Fixation technique used for the } \\
\text { recessed electrode: }\end{array}$ & $\begin{array}{l}\text {-Bone pâté (8) } \\
\text {-Bone pâté + bony overhang (11) } \\
\text {-Sutures + bony overhang (1) } \\
\text { Sutures + fibrin glue (1) }\end{array}$ & $\begin{array}{l}\text {-Bone pâté (13) } \\
\text {-Bone pâté + bony overhang (2) } \\
\text {-Sutures + bony overhang (2) } \\
\text {-Sutures + fibrin glue (1) } \\
\text { No fixation (7) }\end{array}$ \\
\hline $\begin{array}{l}\text { Electrode insertion was performed } \\
\text {-Via the round window } \\
\text {-Via cochleostomy }\end{array}$ & $\begin{array}{c}12 \\
8\end{array}$ & $\begin{array}{l}15 \\
11\end{array}$ \\
\hline
\end{tabular}


in 8 subjects. There were 6 subjects who had had previous contralateral CI implantation.

For surgical details, see Table 1 . The average time between surgery and last follow-up visit for all adult subjects implanted with the non-pin variant was 7.1 months (range 1.1-8.3 months; median 7.2 months). For 20 subjects the implant was judged as being stable both during surgery and at each follow-up visit; however, 1 subject discontinued the study prematurely and in this case the implant was also judged as stable up to the last follow-up visit.

\section{Group 2: Children implanted with the non-pin variant}

There were 26 children implanted with the non-pin variant, 10 female and 16 male. Average age at implantation was 4.5 years (range $0.6-16.9$; median 2.5 years). For 17 subjects the implantation was on the right and for 9 on the left. The etiology of hearing loss for the implanted ear was congenital/hereditary for 24 , otosclerosis for 1 , and meningitis for 1 . The average duration of hearing impairment for the implanted ears was 3.8 years (range 7 months - 12 years; median 2 years) and unknown for 4 subjects. There were 6 subjects who had had previous contralateral CI implantation.
For surgical details, see Table 1. The average time between surgery and last follow-up visit for all children implanted with the non-pin variant was 6.7 months (range 1.1-10.5 months; median 7.1 months). Three subjects were withdrawn from the study: 1 was withdrawn due to device malfunction (which was related to a head trauma of the child and led to explantation of the study device, see adverse events) and 2 were lost to follow-up. One subject discontinued the study prematurely. The implant was judged as being stable for all cases both during surgery and at each follow-up visit for all subjects, including those who discontinued the study prematurely.

\section{Group 3: Adults implanted with the pin variant}

There were 28 adults implanted with the pin variant, 17 female and 11 male. Average age at implantation was 56.3 years (range 23.4-78.1; median 60.3 years). There were 10 subjects implanted on the right and 18 on the left. The etiology of hearing loss for the implanted ear was unknown for 9, congenital/hereditary for 6 , progressive or age-related for 2, acute for 2, meningitis plus ototoxicity for 2 , cholesteatoma surgery for 1 , mastoiditis for 1 , otosclerosis for 1, Meniere's disease for 2, measles for 1 , and viral for 1 subject. The average duration of hearing impairment for the implanted ears was 14.4 years (range 1-38 years; median 10 years) and unknown for

Table 2. Surgical details of Groups 3 and 4 (adults and children implanted with the pin variant)

\begin{tabular}{|c|c|c|}
\hline Surgical information & Group $3(n=28)$ & Group $4(n=41)$ \\
\hline Mean length of skin incision & $5.4 \mathrm{~cm}$ (range $3.5-10.0 \mathrm{~cm}$; median $4.0 \mathrm{~cm}$ ) & $5.0 \mathrm{~cm}$ (range $3.0-8.0 \mathrm{~cm}$; median $5.0 \mathrm{~cm}$ ) \\
\hline $\begin{array}{l}\text { Type of skin flap } \\
\text {-Single } \\
\text {-Double }\end{array}$ & $\begin{array}{c}9 \\
19\end{array}$ & $\begin{array}{c}7 \\
34\end{array}$ \\
\hline $\begin{array}{l}\text { Mean depth of the implant bed at the } \\
\text { anterior edge }\end{array}$ & $\begin{array}{c}2.7 \mathrm{~mm} \text { (range } 1.5-4.0 \mathrm{~mm} \text {; } \\
\text { median } 3.0 \mathrm{~mm})\end{array}$ & $\begin{array}{c}1.6 \mathrm{~mm} \text { (range } 0-3.0 \mathrm{~mm} \\
\text { median } 1.5 \mathrm{~mm} \text { ) }\end{array}$ \\
\hline $\begin{array}{l}\text { Mean distance from the anterior } \\
\text { edge of the implant bed to the edge } \\
\text { of the mastoidectomy }\end{array}$ & $\begin{array}{c}12.0 \mathrm{~mm} \text { (range } 8.0-20.00 \mathrm{~mm} \text {; } \\
\text { median } 10.0 \mathrm{~mm} \text { ) }\end{array}$ & $\begin{array}{c}10.4 \mathrm{~mm} \text { (range } 1.0-25.0 \mathrm{~mm} \text {; } \\
\text { median } 10.0 \mathrm{~mm} \text { ) }\end{array}$ \\
\hline $\begin{array}{l}\text { Mean depth of the holes drilled to } \\
\text { accommodate the pins }\end{array}$ & $\begin{array}{l}1.5 \mathrm{~mm} \text { (range } 1.0-2.0 \mathrm{~mm} \text {; median } 1.4 \mathrm{~mm} \text { ) } \\
\text { No holes were drilled in } 1 \text { case } \\
\text { No drilling down to the dura was necessary }\end{array}$ & $\begin{array}{c}1.5 \mathrm{~mm} \text { (range } 0.5-2.0 \mathrm{~mm} \text {; median } 1.5 \mathrm{~mm} \text { ) } \\
\text { No holes were drilled in } 4 \text { cases } \\
\text { Drilling down to the dura was necessary in } \\
12 \text { cases }\end{array}$ \\
\hline $\begin{array}{l}\text { Fixation technique used for the } \\
\text { implant bed }\end{array}$ & $\begin{array}{c}\text { Pins (1) } \\
\text { Bone pâté (15) } \\
\text { Sutures + periosteal pocket (1) } \\
\text { Sutures + bone pâté + periosteal pocket (9) } \\
\text { Sutures + fibrin glue + periosteal pocket (2) }\end{array}$ & $\begin{array}{c}\text { Pins (5) } \\
\text { Bone pâté + pins (3) } \\
\text { Periosteal pocket + pins (13) } \\
\text { Sutures + periosteal pocket (3) } \\
\text { Sutures + bone pâté + periosteal pocket (11) } \\
\text { Sutures + fibrin glue + periosteal pocket (6) }\end{array}$ \\
\hline $\begin{array}{l}\text { Suture fixation technique used: } \\
\text {-Single stitch } \\
\text {-Web stitch }\end{array}$ & $\begin{array}{c}0 \\
28\end{array}$ & $\begin{array}{c}0 \\
41\end{array}$ \\
\hline $\begin{array}{l}\text { Electrode recessed in a ramp-like } \\
\text { channel: } \\
\text { Completely recessed } \\
\text { Partially recessed } \\
\text { Not recessed }\end{array}$ & $\begin{array}{c}13 \\
15 \\
0\end{array}$ & $\begin{array}{l}17 \\
13 \\
11\end{array}$ \\
\hline $\begin{array}{l}\text { Fixation technique used for the } \\
\text { recessed electrode: }\end{array}$ & $\begin{array}{l}\text { Bone pâté (18) } \\
\text { Tunnel (3) } \\
\text { Bone pâté + tunnel (2) } \\
\text { Fibrin glue + tunnel (1) } \\
\text { Sutures + fibrin glue (3) } \\
\quad \text { No fixation (1) }\end{array}$ & $\begin{array}{c}\text { Bone pâté (18) } \\
\text { Bone pâté + tunnel (1) } \\
\text { Periosteal flap (1) } \\
\text { Sutures + tunnel (1) } \\
\text { Sutures + fibrin glue (5) } \\
\text { No fixation (4) }\end{array}$ \\
\hline $\begin{array}{l}\text { Electrode insertion was performed } \\
\text {-Via the round window } \\
\text {-Via cochleostomy }\end{array}$ & $\begin{array}{c}22 \\
6\end{array}$ & $\begin{array}{l}28 \\
13\end{array}$ \\
\hline
\end{tabular}




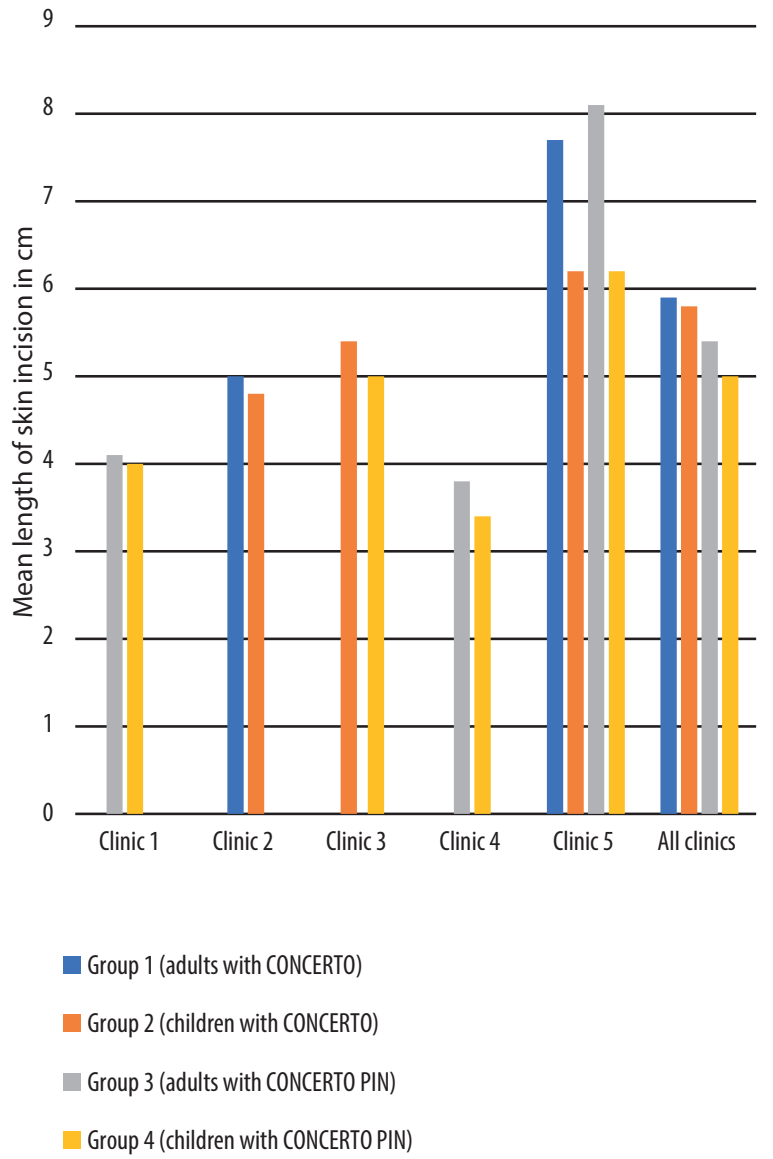

Figure 3. Differences in incision length $(\mathrm{cm})$ between the 5 clinics and for all clinics combined

5 subjects. There were 2 subjects who had had previous contralateral CI implantation.

For surgical details, see Table 2. The average time between surgery and last follow-up visit for all adult subjects implanted with the pin variant was 8.5 months (range 6.0-15.3; median 7.8 months). No subject in this group discontinued the study prematurely. The implant was judged as stable for all cases both during surgery and at each follow-up visit.

\section{Group 4: Children implanted with the pin variant}

There were 41 children implanted with the pin variant, 22 female and 19 male. Average age at implantation was 4.2 years (range 0.9-12.7 years; median 3.1 years); 22 subjects were implanted on the right and 19 on the left. The etiology of hearing loss for the implanted ear was unknown for 1 , congenital/hereditary for 36 , viral for 2 , and trauma for 2 subjects. The average duration of hearing impairment for the implanted ears was 3.7 years (range 10 months 12 years; median 2.5 years) and unknown for 2 subjects. There were 13 subjects who had had previous contralateral CI implantation.

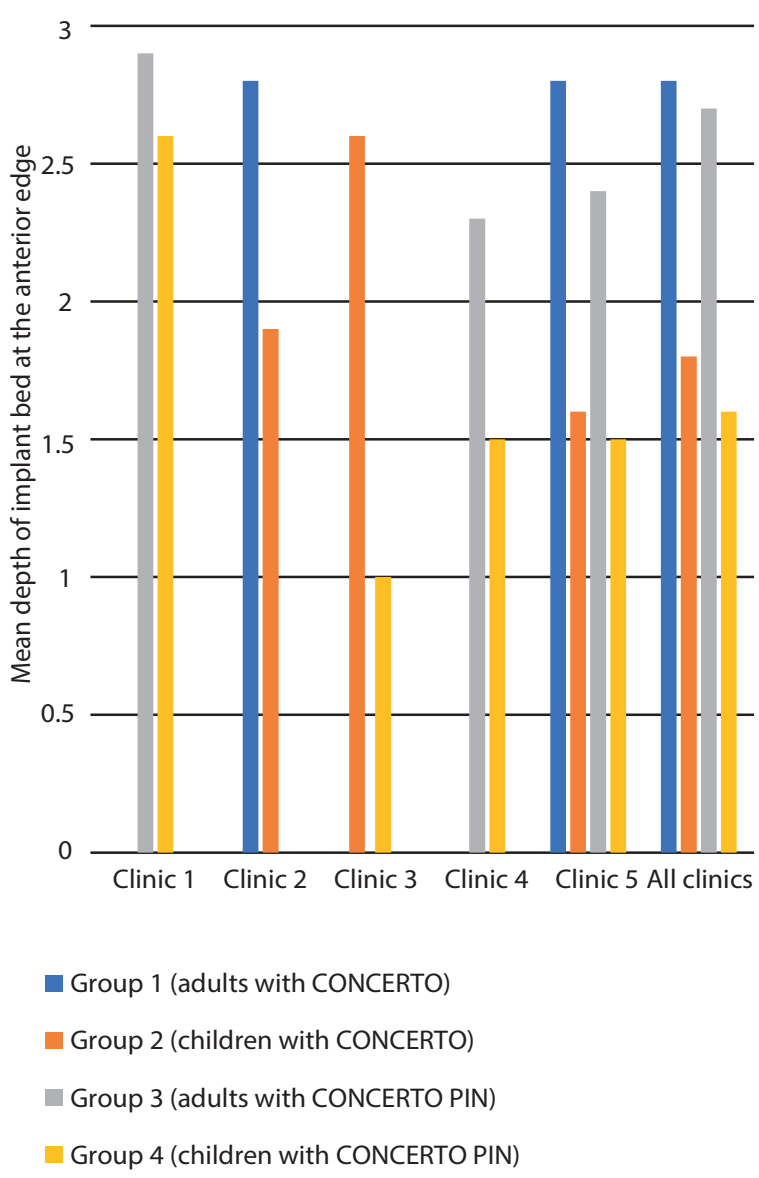

Figure 4. Differences in mean depth of implant bed $(\mathrm{mm})$ between clinics

For surgical details, see Table 2. The average time between surgery and last follow-up visit for all children implanted with the pin variant was 6.8 months (range 1.1-11.1; median 6.6 months). Three subjects discontinued the study prematurely. The implant was judged as being stable for all cases both during surgery and at each follow-up visit for all subjects, including those who discontinued the study prematurely.

\section{Comparison of the surgical outcomes between the groups}

Statistical analysis showed that there was no significant difference between children and adults regarding the length of skin incision $(p=0.70)$. In one clinic, larger skin incisions $(6.0-8.0 \mathrm{~cm})$ were performed while all other clinics used skin incisions between 4.0 and $6.0 \mathrm{~cm}$. See Figure 3 .

An implant bed was drilled for the electronics pack for 113 subjects only. In 3 children implanted in one clinic, no implant bed was drilled at all. The mean depth of the implant bed at the anterior edge was more than $2.3 \mathrm{~mm}$ (range 1.5-5.0 mm) for adult subjects. For children, a depth of the implant bed of between 1.0 and $1.9 \mathrm{~mm}$ was reported by three clinics. One clinic reported a mean depth of the implant bed of $2.6 \mathrm{~mm}$ (range $2.0-3.0 \mathrm{~mm}$ ) for children implanted with the pin variant; in another clinic the 


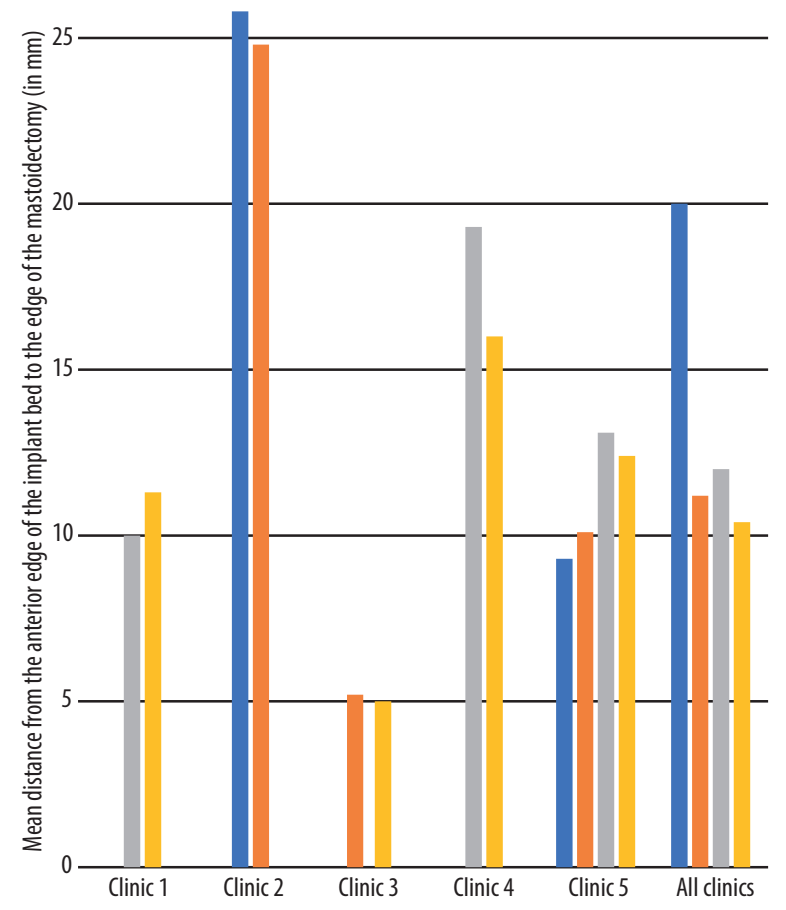

Group 1 (adults with CONCERTO)

Group 2 (children with CONCERTO)

Group 3 (adults with CONCERTO PIN)

Group 4 (children with CONCERTO PIN)

Figure 5. Mean depth of implant bed ( $\mathrm{mm}$ ) according to clinic

mean depth of the implant bed was $2.6 \mathrm{~mm}$ (range 2.0$3.0 \mathrm{~mm}$ ) for children implanted with the non-pin variant, and a shallower implant bed (mean depth $1.0 \mathrm{~mm}$, range 0.0-2.0 $\mathrm{mm}$ ) for children implanted with the pin variant. See Figure 4. Overall, the depth of the implant bed at the anterior edge was significantly shallower in children than in adults $(p<0.001)$. A significant difference was observed between children and adults implanted with the non-pin variant $(p<0.001)$ and between children and adults implanted with the pin variant $(p<0.001)$. However, the difference of the depth of the implant bed at the anterior edge was not significant between children implanted with the non-pin variant and children implanted with the pin variant $(p=0.239)$.

The distance from the anterior edge of the implant bed to the edge of the mastoidectomy varied from $1.0-30.0 \mathrm{~mm}$ in children to $4.0-20.0 \mathrm{~mm}$ in adults (see Table 1 and Table 2). For the mean values of the distance from the anterior edge of the implant bed to the edge of the mastoidectomy stratified by groups and clinics, see Figure 5.

In 3 children implanted with the pin variant, drilling the implant bed exposed the dura and precluded the drilling of holes to accommodate the pins. Holes were drilled in all adults implanted with the pin variant. In the majority of cases, regular diamond drills (drill sizes ranging from
0.5 to $2.0 \mathrm{~mm}$ ) which are generally available in the operating room were used.

\section{Adverse events}

We observed 33 adverse events (AEs) during the study. Of these, 9 were classified as adverse device effects (ADEs) related to the device or procedure: 2 cases of retroauricular edema, 2 cases of vertigo, 2 cases of putting the coil into the mouth (both reports from one mentally retarded child), 1 case of skin irritation, 1 case of pain over the implant, and 1 case of emphysema around the implant. One was classified as a serious adverse device event (SADE) related to the device or procedure. In this case, implant explantation was required, most likely due to a head trauma which happened to the child 2 weeks before a determination of device failure. The head trauma itself did not lead to hospitalisation of the subject. The overall rate of adverse events $(\mathrm{ADE}+\mathrm{SADE})$ related to the device or procedure was $8.6 \%$. All device- or procedure-related adverse events were generally related to cochlear implantation but were not specifically related to the cochlear implant variants investigated in this study. Table 3 shows a full list of all adverse events that were documented throughout the study.

Considering differences in sample size between the 4 groups, the incidence of adverse events related to the device or procedure was lowest in Group 4 (children implanted with the pin variant), followed by Group 2 (children implanted with the non-pin variant), Group 3 (adults implanted with the pin variant), and Group 1 (adults implanted with the non-pin variant). The same order can be seen when considering the overall incidence of adverse events. Table 4 shows the total number and percentages of adverse events in each group as well as for the entire study population.

\section{Discussion}

The primary aim of this study was to collect information on the surgical procedures used to implant two cochlear implant variants (non-pin and pin) in adults and children and to assess their medium-term stability. A secondary aim was to assess their safety. The results confirm that both implant variants are stable and a safe treatment option for both adults and children.

Implantations were done on 116 adults and children using either the non-pin or pin variant and followed up for 1.1 to 15.3 months (mean 7.2 months) after surgery. Stability was tested by gently feeling the receiver-stimulator. No shifting or rocking of the implant was observed throughout the study. Safety was assessed based on the number and severity of adverse events. Device- or procedure-related adverse event rates and overall adverse event rates were lower in children than in adults. Device- or procedure-related adverse event rates were equal or lower in adults and children implanted with the pin variant compared to adults and children implanted with the non-pin variant (although with the pin variant additional suture fixation was omitted in more than $50 \%$ of the implanted adults and children). The only explantation required was due to head trauma in a child. Besides this, only minor adverse events were reported which were all resolved 
Table 3. Adverse events (AEs) reported during the study with description and final classification

\begin{tabular}{|c|c|c|c|c|c|c|}
\hline $\begin{array}{l}\text { Subject ID / } \\
\text { Group }\end{array}$ & $\begin{array}{l}\text { Start of the } \\
\qquad A E\end{array}$ & $\begin{array}{l}\text { Stop of the } \\
\qquad A E\end{array}$ & Description of the AE & $\begin{array}{l}\text { Relation } \\
\text { to IMD }\end{array}$ & Action required & Class \\
\hline $\begin{array}{l}\text { CONIBK001 } \\
\text { Group } 3\end{array}$ & 05Feb2012 & 20Feb2012 & Influenza & $\begin{array}{l}\text { Definitely } \\
\text { not }\end{array}$ & None & $\mathrm{AE}$ \\
\hline $\begin{array}{l}\text { CONIBK015 } \\
\text { Group } 3\end{array}$ & 06Feb2012 & 13Feb2012 & $\begin{array}{l}\text { Late post-operative } \\
\text { facial palsy }\end{array}$ & $\begin{array}{l}\text { Definitely } \\
\text { not }\end{array}$ & $\begin{array}{c}\text { Medical intervention without } \\
\text { hospitalization: cortisone therapy } \\
\text { parenteral }\end{array}$ & $\mathrm{AE}$ \\
\hline $\begin{array}{l}\text { CONRDI009 } \\
\text { Group } 1\end{array}$ & Feb2012 & Feb2012 & $\begin{array}{l}\text { At a skiing accident, } \\
\text { the patient broke a } \\
\text { lumbar vertebra }\end{array}$ & $\begin{array}{l}\text { Probably } \\
\text { not }\end{array}$ & $\begin{array}{c}\text { Medical intervention without } \\
\text { hospitalization: a spine corset was } \\
\text { applied, subject has no functional } \\
\text { impairment }\end{array}$ & $\mathrm{AE}$ \\
\hline $\begin{array}{l}\text { CONVAKO03 } \\
\text { Group } 4\end{array}$ & 27Jan2012 & 03Feb2012 & $\begin{array}{l}\text { OMA (acute otitis } \\
\text { media) with bloody } \\
\text { suppurative discharge }\end{array}$ & $\begin{array}{l}\text { Definitely } \\
\text { not }\end{array}$ & $\begin{array}{c}\text { Medical intervention without } \\
\text { hospitalization: oral antibiotics \& } \\
\text { homeopathic globuli administered by } \\
\text { resident ENT specialist }\end{array}$ & $\mathrm{AE}$ \\
\hline $\begin{array}{l}\text { CONWUB003 } \\
\text { Group } 1\end{array}$ & 01Jul2010 & ongoing & $\begin{array}{l}\text { Visus reduction } \\
\text { possibly due to } \\
\text { Cordarex medication }\end{array}$ & $\begin{array}{l}\text { Definitely } \\
\text { not }\end{array}$ & $\begin{array}{l}\text { Medical intervention without } \\
\text { hospitalization: ongoing treatment } \\
\text { for pre-existing condition; } \\
\text { hospitalization planned to exchange } \\
\text { medication }\end{array}$ & $\mathrm{AE}$ \\
\hline $\begin{array}{l}\text { CONWUB003 } \\
\text { Group } 1\end{array}$ & 25Jul2011 & 25Jul2011 & Car accident & $\begin{array}{l}\text { Definitely } \\
\text { not }\end{array}$ & $\begin{array}{c}\text { None: car accident without any } \\
\text { health effects }\end{array}$ & $\mathrm{AE}$ \\
\hline $\begin{array}{l}\text { CONWUB004 } \\
\text { Group } 2\end{array}$ & 20Jun2011 & unknown & $\begin{array}{l}\text { Infection of upper } \\
\text { airway with fluid in the } \\
\text { middle ear }\end{array}$ & $\begin{array}{l}\text { Definitely } \\
\text { not }\end{array}$ & $\begin{array}{c}\text { Medical intervention without } \\
\text { hospitalization: Xylometazolin nasal } \\
\text { spray for } 7 \text { days NaCl nasal drops for } \\
3 \text { weeks }\end{array}$ & $\mathrm{AE}$ \\
\hline $\begin{array}{l}\text { CONWUB004 } \\
\text { Group } 2\end{array}$ & 25Mar2011 & unknown & $\begin{array}{l}\text { Rash in anal and } \\
\text { bottom region }\end{array}$ & $\begin{array}{l}\text { Definitely } \\
\text { not }\end{array}$ & $\begin{array}{l}\text { Medical intervention without } \\
\text { hospitalization: local ointment }\end{array}$ & $\mathrm{AE}$ \\
\hline $\begin{array}{l}\text { CONWUB008 } \\
\text { Group } 4\end{array}$ & 07Sep2011 & 14Sep2011 & Otitis externa right side & $\begin{array}{l}\text { Definitely } \\
\text { not }\end{array}$ & $\begin{array}{c}\text { Medical intervention without } \\
\text { hospitalization: antibiotics locally and } \\
\text { systemically }\end{array}$ & $\mathrm{AE}$ \\
\hline $\begin{array}{l}\text { CONWUB024 } \\
\text { Group } 4\end{array}$ & 01Sep2012 & 19Sep2012 & $\begin{array}{l}\text { Repeated epistaxis } \\
\text { (roughly } 2-3 \text { times/ } \\
\text { week) starting around } \\
1 \text { Sep12, stopping } \\
\text { spontaneously after } \\
\text { pressure to the nose, } \\
\text { last on } 15 \text { Sep12 }\end{array}$ & $\begin{array}{l}\text { Definitely } \\
\text { not }\end{array}$ & $\begin{array}{l}\text { None: if not stopping spontaneously } \\
\text { + pressure to the nose prescription } \\
\text { of ointment (Bepanthen) to improve } \\
\text { moistening of nasal mucosa on } \\
\text { 20Sep12 to prevent future epistaxis }\end{array}$ & $A E$ \\
\hline $\begin{array}{l}\text { CONWUB029 } \\
\text { Group } 4\end{array}$ & Feb2013 & Feb2013 & Fever 1 day & $\begin{array}{l}\text { Definitely } \\
\text { not }\end{array}$ & None & $\mathrm{AE}$ \\
\hline $\begin{array}{l}\text { CONWUB030 } \\
\text { Group } 1\end{array}$ & unknown & unknown & $\begin{array}{l}\text { Patient described an } \\
\text { 'electric feeling' in the } \\
\text { head, mostly when } \\
\text { she touches synthetic } \\
\text { material or when she } \\
\text { holds her head back, } \\
\text { this happens also when } \\
\text { the processor is not } \\
\text { worn }\end{array}$ & $\begin{array}{l}\text { Probably } \\
\text { not }\end{array}$ & None & $\mathrm{AE}$ \\
\hline $\begin{array}{l}\text { CONWUB031 } \\
\text { Group } 1\end{array}$ & unknown & unknown & $\begin{array}{l}\text { Intermittent increase of } \\
\text { tinnitus and dizziness } \\
\text { (few seconds to } \\
\text { minutes) }\end{array}$ & $\begin{array}{l}\text { Definitely } \\
\text { not }\end{array}$ & None & $\mathrm{AE}$ \\
\hline $\begin{array}{l}\text { CONWUB031 } \\
\text { Group } 1\end{array}$ & $\begin{array}{l}\text { Unknown, } \\
\sim 2 \text { weeks } \\
\text { after } \\
\text { discharge }\end{array}$ & 24Jul2012 & Acute otitis externa & $\begin{array}{l}\text { Definitely } \\
\text { not }\end{array}$ & $\begin{array}{c}\text { Medical intervention without } \\
\text { hospitalization: Cleaning of the } \\
\text { auditory canal (once) antibiotics } \\
\text { ointment (once) by local ENT } \\
\text { specialist }\end{array}$ & $\mathrm{AE}$ \\
\hline $\begin{array}{l}\text { CONWUB031 } \\
\text { Group } 1\end{array}$ & unknown & continuing & $\begin{array}{l}6 \text { weeks ago, acute } \\
\text { exacerbation of chronic } \\
\text { rhinosinusitis. Today } \\
\text { still persisting posterior } \\
\text { rhinorrhoea }\end{array}$ & $\begin{array}{l}\text { Definitely } \\
\text { not }\end{array}$ & $\begin{array}{l}\text { Medical intervention without } \\
\text { hospitalization: initially (acute } \\
\text { rhinosinusitis } 6 \text { weeks ago) self- } \\
\text { treated by subject (mucosolvants } \\
\text { nasal spray). Now: prescription of } \\
\text { Mometason nasal spray 1xday; Under } \\
\text { Mometason nasal spray 1xday no } \\
\text { acute exacerbation during last time }\end{array}$ & $\mathrm{AE}$ \\
\hline $\begin{array}{l}\text { CONWUB033 } \\
\text { Group } 4\end{array}$ & 14Jul2012 & 14Jul2012 & $\begin{array}{l}\text { Fever for } 1 \text { day more } \\
\text { than or equal to } 38^{\circ} \mathrm{C}\end{array}$ & $\begin{array}{c}\text { Probably } \\
\text { not }\end{array}$ & $\begin{array}{l}\text { Medical intervention without } \\
\text { hospitalization: Nurofen }\end{array}$ & $\mathrm{AE}$ \\
\hline
\end{tabular}


Mlynski R. et al. - Implant stability in adults and children...

Table 3. Adverse events (AEs) reported during the study with description and final classification

\begin{tabular}{|c|c|c|c|c|c|c|}
\hline $\begin{array}{l}\text { Subject ID / } \\
\text { Group }\end{array}$ & $\begin{array}{l}\text { Start of the } \\
\qquad A E\end{array}$ & $\begin{array}{l}\text { Stop of the } \\
A E\end{array}$ & Description of the AE & $\begin{array}{l}\text { Relation } \\
\text { to IMD }\end{array}$ & Action required & Class \\
\hline $\begin{array}{l}\text { CONWUB035 } \\
\text { Group } 4\end{array}$ & 090ct2012 & $120 c t 2012$ & $\begin{array}{c}\text { Beginning otitis media } \\
\text { left }\end{array}$ & $\begin{array}{l}\text { Probably } \\
\text { not }\end{array}$ & $\begin{array}{l}\text { Medical intervention without } \\
\text { hospitalization: oral antibiotic, nasal } \\
\text { spray, oral anti-inflammatory drug }\end{array}$ & $\mathrm{AE}$ \\
\hline $\begin{array}{l}\text { CONRDI003 } \\
\text { Group } 1\end{array}$ & 05Dec2011 & 05Dec2011 & $\begin{array}{l}\text { Vertigo for several } \\
\text { hours, most likely } \\
\text { related to previously } \\
\text { diagnosed Meniere's } \\
\text { Disease }\end{array}$ & $\begin{array}{l}\text { Probably } \\
\text { not }\end{array}$ & $\begin{array}{l}\text { Hospitalization or prolongation of } \\
\text { hospitalization: Intravenous steroid } \\
\text { treatment }\end{array}$ & SAE \\
\hline $\begin{array}{l}\text { CONRDI003 } \\
\text { Group } 1\end{array}$ & 06Feb2012 & 09Feb2012 & $\begin{array}{l}\text { Meniere vertigo attack } \\
\text { (left side) requiring } \\
\text { hospitalization, quickly } \\
\text { resolving }\end{array}$ & $\begin{array}{l}\text { Probably } \\
\text { not }\end{array}$ & $\begin{array}{l}\text { Hospitalization or prolongation of } \\
\text { hospitalization: Intravenous steroid } \\
\text { treatment }\end{array}$ & SAE \\
\hline $\begin{array}{l}\text { CONRDI003 } \\
\text { Group } 1\end{array}$ & 20Feb2012 & 22Feb2012 & $\begin{array}{l}\text { Meniere vertigo attack } \\
\text { (left side) requiring } \\
\text { hospitalization, quickly } \\
\text { resolving }\end{array}$ & $\begin{array}{l}\text { Probably } \\
\text { not }\end{array}$ & $\begin{array}{l}\text { Hospitalization or prolongation of } \\
\text { hospitalization: Intravenous steroid } \\
\text { treatment }\end{array}$ & SAE \\
\hline $\begin{array}{l}\text { CONWUB006 } \\
\text { Group } 3\end{array}$ & Apr2010 & 18Nov2011 & $\begin{array}{l}\text { Carpal tunnel } \\
\text { syndrome }\end{array}$ & $\begin{array}{l}\text { Definitely } \\
\text { not }\end{array}$ & $\begin{array}{l}\text { Medical intervention to prevent } \\
\text { permanent impairment: Operation of } \\
\text { the carpal tunnel on } 180 \text { ct } 2011\end{array}$ & SAE \\
\hline $\begin{array}{l}\text { CONWUB019 } \\
\text { Group } 1\end{array}$ & Feb2012 & 27Apr2012 & $\begin{array}{l}\text { Pain of the cervical } \\
\text { spine for } 6 \text { weeks }\end{array}$ & $\begin{array}{l}\text { Probably } \\
\text { not }\end{array}$ & $\begin{array}{l}\text { Hospitalization or prolongation of } \\
\text { hospitalization: Hospitalization for } \\
\text { medical pain therapy was necessary }\end{array}$ & SAE \\
\hline $\begin{array}{l}\text { CONWUB044 } \\
\text { Group } 2\end{array}$ & $060 c t 2013$ & $220 c t 2013$ & $\begin{array}{l}\text { Acute obstruction } \\
\text { bronchitis, } \\
\text { hospitalization } \\
20.10 .13-22.10 .13\end{array}$ & $\begin{array}{l}\text { Definitely } \\
\text { not }\end{array}$ & $\begin{array}{l}\text { Hospitalization or prolongation of } \\
\text { hospitalization: Salbubronch, Lapeal, } \\
\text { Salbutamol, Ipratropiumbromide. Start } \\
\text { and stop dates of medications unknown }\end{array}$ & SAE \\
\hline $\begin{array}{l}\text { CONIBKO03 } \\
\text { Group } 3\end{array}$ & 22Aug2011 & 10Sep2011 & $\begin{array}{l}\text { Minimal oedema over } \\
\text { the skin flap/temporal, } \\
\text { no treatment necessary, } \\
\text { no acute infection }\end{array}$ & $\begin{array}{l}\text { Definitely } \\
\text { yes }\end{array}$ & None & ADE \\
\hline $\begin{array}{l}\text { CONIBK008 } \\
\text { Group } 3\end{array}$ & 27Jan2012 & 05Feb2012 & oedema retroauricular & $\begin{array}{l}\text { Probably } \\
\text { yes }\end{array}$ & $\begin{array}{l}\text { Medical intervention without } \\
\text { hospitalization: Amoxicillin/ } \\
\text { Clavulanic acid 1g 2xday for } 10 \text { days }\end{array}$ & ADE \\
\hline $\begin{array}{l}\text { CONRDI008 } \\
\text { Group } 1\end{array}$ & $110 c t 2011$ & $230 c t 2011$ & $\begin{array}{l}\text { Mild vertigo from time } \\
\text { to time }\end{array}$ & $\begin{array}{c}\text { Probably } \\
\text { yes }\end{array}$ & $\begin{array}{l}\text { Medical intervention without } \\
\text { hospitalization: Training of balance }\end{array}$ & $A D E$ \\
\hline $\begin{array}{l}\text { CONRDI013 } \\
\text { Group } 1\end{array}$ & 10Jul2012 & 17Jul2012 & $\begin{array}{l}\text { Skin irritation (red skin } \\
\text { colour) over implant }\end{array}$ & Possibly & $\begin{array}{l}\text { Medical intervention without } \\
\text { hospitalization: Local soothing } \\
\text { skin cream }\end{array}$ & ADE \\
\hline $\begin{array}{l}\text { CONRDI017 } \\
\text { Group } 3\end{array}$ & unknown & 07Dec2013 & Pain at side of implant & $\begin{array}{l}\text { Probably } \\
\text { yes }\end{array}$ & $\begin{array}{l}\text { Medical intervention without } \\
\text { hospitalization: Magnet } \\
\text { strength reduced }\end{array}$ & $\mathrm{ADE}$ \\
\hline $\begin{array}{l}\text { CONWUB012 } \\
\text { Group } 2\end{array}$ & $290 c t 2011$ & $290 c t 2011$ & $\begin{array}{l}\text { The patient put the coil } \\
\text { of the implant into the } \\
\text { mouth, due to mentally } \\
\text { retarded illnesses }\end{array}$ & $\begin{array}{l}\text { Definitely } \\
\text { yes }\end{array}$ & $\begin{array}{l}\text { Medical intervention without } \\
\text { hospitalization: The coil was removed } \\
\text { by an emergency physician at the } \\
\text { patient's home. Mild bleeding of the } \\
\text { mouth was observed (oral cavity) }\end{array}$ & ADE \\
\hline $\begin{array}{l}\text { CONWUB012 } \\
\text { Group } 2\end{array}$ & 20Nov2011 & 20Nov2011 & $\begin{array}{l}\text { The patient put the } \\
\text { coil again into the } \\
\text { mouth, due to mentally } \\
\text { retarded illnesses }\end{array}$ & $\begin{array}{l}\text { Definitely } \\
\text { yes }\end{array}$ & $\begin{array}{c}\text { Medical intervention without } \\
\text { hospitalization: The coil was removed } \\
\text { by an emergency physician after } \\
\text { sedation of the patient }\end{array}$ & $\mathrm{ADE}$ \\
\hline $\begin{array}{l}\text { CONWUB017 } \\
\text { Group } 3\end{array}$ & 08Dec2011 & 15Dec2011 & $\begin{array}{l}\text { Emphysema around } \\
\text { implant after blowing } \\
\text { the nose }\end{array}$ & $\begin{array}{l}\text { Definitely } \\
\text { not }(\mathrm{PI})\end{array}$ & $\begin{array}{c}\text { Medical intervention without } \\
\text { hospitalization: Puncture, dressing, } \\
\text { antibiotics }\end{array}$ & $\mathrm{ADE}$ \\
\hline $\begin{array}{l}\text { CONWUB030 } \\
\text { Group } 1\end{array}$ & unknown & unknown & Vertigo & Possibly & $\begin{array}{c}\text { Medical intervention without } \\
\text { hospitalization: Medication with } \\
{\text { Vertigohee }{ }^{\circledast}}\end{array}$ & $A D E$ \\
\hline $\begin{array}{l}\text { CONRNS011 } \\
\text { Group } 2\end{array}$ & 04Apr2013 & unknown & $\begin{array}{l}\text { The patient had a head } \\
\text { trauma } 2 \text { weeks ago. } \\
\text { The patient was not } \\
\text { hospitalized. Today there } \\
\text { are no impedance on any } \\
\text { electrodes, the implant } \\
\text { is probably broken. } \\
\text { We decide explantation } \\
\text { and reimplantation } \\
\text { scheduled on April } 8^{\text {th }}\end{array}$ & $\begin{array}{l}\text { Definitely } \\
\text { yes }\end{array}$ & $\begin{array}{l}\text { Medical intervention to prevent } \\
\text { permanent impairment: explantation } \\
\text { and reimplantation } \\
\text { AE resolved after reimplantation, } \\
\text { no further treatment required }\end{array}$ & SADE \\
\hline
\end{tabular}


Table 4. Overview of the observed occurrence rates for adverse events (AEs) in groups 1 to 4 and in the entire study population

\begin{tabular}{lccccccc}
\hline & $\boldsymbol{n}$ & $\begin{array}{c}\text { AEs } \\
\mathbf{n}(\%)\end{array}$ & $\begin{array}{c}\text { SAEs } \\
\mathbf{n}(\%)\end{array}$ & $\begin{array}{c}\text { ADEs } \\
\mathbf{n}(\%)\end{array}$ & $\begin{array}{c}\text { SADEs } \\
\boldsymbol{n}(\%)\end{array}$ & $\begin{array}{c}\text { ADE + SADE } \\
\boldsymbol{n}(\%)\end{array}$ & $\begin{array}{c}\text { Overall } \\
\boldsymbol{n}(\%)\end{array}$ \\
\hline Group 1 & 21 & $7(33.3 \%)$ & $4(19.0)$ & $3(14.3)$ & 0 & $3(14.3 \%)$ & $14(66.7 \%)$ \\
\hline Group 2 & 26 & $2(7.7 \%)$ & $1(3.8 \%)$ & $2(7.7 \%)$ & $1(3.8 \%)$ & $3(11.5 \%)$ & $6(23.1 \%)$ \\
\hline Group 3 & 28 & $2(7.1 \%)$ & $1(3.6 \%)$ & $4(14.3 \%)$ & 0 & $4(14.3 \%)$ & $7(25.0 \%)$ \\
\hline Group 4 & 41 & $6(14.6 \%)$ & 0 & 0 & 0 & 0 & $6(14.6 \%)$ \\
\hline Total & 116 & $17(14.6 \%)$ & $6(5.2 \%)$ & $9(7.8 \%)$ & $1(0.9 \%)$ & $10(8.6 \%)$ & $33(28.4 \%)$ \\
\hline
\end{tabular}

AE: adverse event; SAE: serious adverse event; ADE: adverse device event; SADE: serious adverse device event

within a short time and which had no effect on implant stability in any of the cases. The rate of reported minor and major device- or procedure-related adverse events compares well with adverse event rates reported in the literature [10,17-19].

The present study also confirms the safety of the non-pin variant and the pin variant in combination with different surgical techniques, at least in the short to medium term. The relatively short follow-up period does not allow a conclusion to be drawn on long term complications. However, Arnoldner and colleagues [18] showed that surgery-related complications are more likely in the 3 months immediately after surgery than in later time-frames.

Positive outcomes were achieved by all surgical teams using different surgical methods. In particular, the distance from the anterior edge of the implant bed to the edge of the mastoidectomy varied widely between the study groups depending on the surgeon's preferred technique. This suggests that both the non-pin variant and the pin variant are suitable for different surgical approaches and that these differences have no influence on implant stability or safety.

Interestingly, no significant difference was observed between children and adults in the depth of the hole to accommodate the pins. This is in contrast to the depth of the implant bed which was found to be significantly shallower in children than in adults. Nevertheless, exposure of the dura was reported for 12/41 children but for none of the 28 adults implanted with the pin variant. This reflects the reduced thickness of the skull in children compared to adults, a fact which needs to be considered during implantation. Schnabl et al. [14] showed that the pin variant is a good treatment option for subjects with thinner bone, such as children. Further evidence for this is provided in the present study, with the lowest rate of deviceor procedure-related adverse events seen in the pediatric subjects (Groups 2 and 4).

The most relevant surgical differences can be observed in the implant fixation techniques. Additional suture fixation was performed in every subject implanted with the non-pin variant (Groups 1 and 2). In 39 cases of Groups 1 and 2, dissolvable sutures were used for fixation whereas permanent sutures were used in only 7 cases. However, in the group of adult subjects implanted with the pin variant (Group 3), suture fixation was performed in only 12 cases. In 16 cases, implant fixation was performed without sutures. In the group of children implanted with the pin variant, suture fixation was performed in 20 cases. In 21 cases, implant fixation was performed without sutures. The non-suture fixation approach deviates from the manufacturer's surgical guidelines which suggest recessing the pins and immobilising the stimulator with non-dissolvable (permanent) sutures in order to avoid postoperative movement that may result in mechanical fatigue and subsequent premature failure of electrical connections. However, the results of this study show that implant stability can also be achieved without additional suture fixation and they suggest that omitting additional suture fixation does not lead to an increased risk of device migration if the pin variant is used in combination with a periosteal pocket. This confirms the findings of a previous study that examined a fixation technique involving a periosteal pocket without sutures [10].

\section{Limitations}

A limitation of this study is that no objective measurement of the implant stability was performed. In our study, implant stability was subjectively tested by gently feeling the receiver-stimulator. Another limitation is that the followup period extended only to 7 months.

\section{Conclusions}

Implant stability and safety can be achieved even when different surgical techniques and fixation methods are employed.

\section{Conflicts of interest and source of funding:}

The study was supported by Med-El (Innsbruck, Austria). The authors do not have financial relationships with the organisation that sponsored the research.

\section{Research involving human participants and informed consent:}

All study participants gave written informed consent. Ethics committee approval was obtained by all clinics involved in the study.

\section{Acknowledgements}

The authors thank Edda Amann for statistical analysis and Martin Eisendle and Ursula Lehner-Mayrhofer for medical writing assistance. 


\section{References:}

1. Davis BM, Labadie RF, McMenomey SO, Haynes DS. Cochlear implant fixation using polypropylene mesh and titanium screws. Laryngoscope, 2004;114 (12): 2116-8.

2. Mangus B, Rivas A, Tsai BS, Haynes DS, Roland JT. Surgical techniques in cochlear implants. Otolaryngol Clin North Am, 2012; 45 (1): 69-80.

3. Mlynski R, Rak K, Kaulitz S, Kraus F, Hagen R, Radeloff A. New bone and fibrous tissue formation around ceramic cochlear implant receiver-stimulators and the measurement of their anchorage in the bony implant bed. Cochlear Implants Int, 2014; 15(6): 327-32.

4. Stark T, Niedermeyer HP, Knopf A, Sudhoff H. Surgical technique for implantation of the MED-EL SONATA TI. ORL J Otorhinolaryngol Relat Spec, 2011; 73(4): 196-200.

5. Balkany TJ, Whitley M, Shapira Y, et al. The temporalis pocket technique for cochlear implantation: an anatomic and clinical study. Otol Neurotol, 2009; 30(7): 903-7.

6. Davids T, Ramsden JD, Gordon KA, James AL, Papsin BC. Soft tissue complications after small incision pediatric cochlear implantation. Laryngoscope, 2009; 119(5): 980-3.

7. Lee DJ, Driver MS. Cochlear implant fixation using titanium screws. Laryngoscope, 2005; 115(5): 910-11.

8. Djalilian HR, King T, Faust RA, Smith S, Levine SC. Securing cochlear implants to the skull: two alternate methods. Ear Nose Throat J, 2001; 80(3): 171-3.

9. Adunka OF, Buchman CA. Cochlear implant fixation in children using periosteal sutures. Otol Neurotol, 2007; 28(6): 768-70.

10. Sweeney AD, Carlson ML, Valenzuela CV, et al. 228 cases of cochlear implant receiver-stimulator placement in a tight subperiosteal pocket without fixation. Otolarnygol Head Neck Surg, 2015; 152(4): 712-7.
11. Gekeler J, Luers JC, Lang-Roth R, Beutner D. Cochlear implant fixation: are sutures really necessary? Eur Arch Otorhinolaryngol, 2013; 270(2): 483-7.

12. Loh C, Jiang D, Dezso A, Fitzgerald O'Connor A. Non-sutured fixation of cochlear implants using a minimally-invasive approach. Clin Otolaryngol, 2008; 33(3): 259-61.

13. O’Donoghue GM, Nikolopoulos TP. Minimal access surgery for pediatric cochlear implantation. Otol Neurotol, 2002; 23(6): 891-4.

14. Schnabl J, Wolf-Magele A, Pok SM, Url C, Zorowka P, Sprinzl G. Evaluation of a minimally invasive surgical fixation technique for young children with the Concerto Pin cochlear implant system. Eur Arch Otorhinolaryngol, 2015; 272(8): 1893-8.

15. Kanonidou Z, Karystianou G. Anesthesia for the elderly. Hippokratia, 2007; 11(4): 175-177.

16. Mueller J, Baumgartner W-D, Godey B, et al. The MED-EL SONATA TI 100 cochlear implant: an evaluation of its safety in adults and children. Acta Otolaryngol, 2011; 131(5): 504-11.

17. Schnabl J, Markl A, Hormann R, Wolf-Magele A, Schartinger V, Sprinzl G. Concerto Pin: a novel concept of cochlear implant fixation. Otol Neurotol, 2012; 33(9): 1525-9.

18. Postelmans JT, Cleffken B, Stokroos RJ. Post-operative complications of cochlear implantation in adults and children: five years' experience in Maastricht. J Laryngol Otol, 2007; 121(4): 318-23.

19. Arnoldner C, Baumgartner WD, Gstoettner W, Hamzavi J. Surgical considerations in cochlear implantation in children and adults: a review of 342 cases in Vienna. Acta Otolaryngol, 2005; 125(3): 228-34. 